\title{
Pediatric Oral Systemic Health: From Fetus to Adolescence
}

\author{
Mark Cannon* and John Peldyak \\ Division of Dentistry, Department of Clinical Otolaryngology, Northwestern University, Chicago, IL, USA
}

*Corresponding author: Mark Cannon, Division of Dentistry, Department of Clinical Otolaryngology, Northwestern University, Chicago, IL, USA

\begin{abstract}
The oral systemic health link has now become well recognized and numerous publications have discussed the importance of the oral microbiome in the overall health of any individual. This is likely even more important in children and this influences their future health as they mature. What is particularly interesting is that the microbiome of a child is developed prior to birth and is related to the maternal oral microbiome. Early intervention to the mother prior to the child's birth, with proper sleep, exercise and dietary adjustments such as the limitation of added sugars and use of coconut oil, for example, will influence the developing child's microbiome. Direct influence with the polyols xylitol and erythritol to reduce pathogens, and probiotics to boost levels of commensals would also be required. Due to the extent of oral disease, and its tremendous associated costs, urgent action is required by all health professions.
\end{abstract}

\section{Introduction}

Every species depends on adaptation to survive. Humans have managed to survive and flourish while directly influencing the environment of the entire planet, encompassing all other forms of life. While there may be philosophical disagreements as to the inadvertent harm to our natural surroundings, the human species, homo sapiens, has been the only survivor of the hominins [1]. The biology of this success is intertwined in the coevolution of homo sapiens and the associated holobiome [2,3]. Chronic illnesses and debilitations appear to be increasing, requiring reflection into the evolutionary process, and the perturbations that have recently occurred creating this environment of now-declining health [4]. Current research would point to the "Hygiene hypothesis", overuse of anti-microbials, dietary shifts and the resultant decrease in human microbiome diversity [5,6]. The old model of looking for an increase in pathogens is flawed. Indeed, the fault lies with the decrease in commensals that not only compete directly with the pathogens, but also modulate the immune response of the host [7]. To improve the health of children, we must first improve the microbiome of the mother. The maternal microbiome sets the stage for the child's microbiome $[8,9]$.

Pre-natal intervention has been studied with positive results reported by the supplementation of the mother with probiotics or polyols $[10,11]$. Published studies using xylitol that involve the nursing mother and child have demonstrated the decrease in the maternal transmission of mutans streptococci [12]. Certainly, intervention may be desired even earlier, preferably before pregnancy because it is also reported that antecedent use of antibiotics by the mother will influence the maternal microbiome [13]. The placental microbiome is most closely related to the maternal oral microbiome [14]. The presence of commensal bacteria in the placenta and developing fetus is essential to fetal immunological maturation [15]. The oral health of the expectant mother should then be considered primarily important to the oral systemic health of the fetus and later, the child. In addition, the placental microbiome appears to be developed quite early in the pregnancy, by maternal imprinting [14]. This maternal imprinting involves the transportation of viable commensals via circulating monocytes, properly creating a fetal microbiome to program the developing child [16]. Animal studies have demonstrated the transmission of maternal breast commensals into the amniotic fluid [17]. All this depends upon the mother actually having a healthy microbiome [18]. The maternal microbiome can be influenced in numerous ways including diet, exercise and probiotic supplementation [19-22]. Limiting added dietary sugar and the regular addition of polyols can help decrease the prevalence of pathogens before they are passed on to the child [12,23-25]. In the case of Early Childhood Caries, the reduction of maternal Candida albicans will reduce the biofilm formation by Streptococcus mutans potentially reducing the incidence of dental caries [26,27]. Some Lactobacilli, all probiotics such as Lactobacilli rhamnosus, have been demonstrated to inhibit Candida albicans [28-30]. Other 
supplements, such as $\mathrm{N}$-acetyl cysteine, also have a reducing effect on Candida albicans levels [31-32]. Coconut oil in the form of Medium Chain Triglycerides (MCT) supplements has also been used to reduce levels of Candida albicans and is reportedly as effective as ketoconazole [33-35]. But it has also been reported that coconut oil has more beneficial components than just MCT, giving pause as to why whole coconut oil isn't utilized more [36]. Regardless, MCT may increase exercise endurance and encourage weight loss [37]. In addition, another natural product, propolis has also been demonstrated to inhibit Candida albicans and other oral pathogens [38-40]. If the expectant mother increases exposure to coconut oil or N-AC, the inhibitory effects may be beneficial in preventing the onset of ECC or, possibly Candida albicans systemic disease if prematurely born [41].

Vitamin K2 has also been reported as being very beneficial as an anti-caries agent and for activation of proper bone and dentin formation in concert with vitamins A and D [42]. This research isn't new, but recently furthered explored and reported [43]. Insufficient levels of Vitamin D have been linked to S-ECC in a number of studies [44-47]. With increased publications of the beneficial properties of these supplements, it is surprising that the dental profession has not enthusiastically adopted a more fully energetic policy on their role in preventing ECC, especially considering the lack of important micronutrients in the typical American fast food diet [48]. The method of birth has been greatly researched demonstrating that C-section results in an increase in childhood allergies and asthma [49]. The research implicates the lack of exposure to the bacteria of the birth canal and anus as being causative with the neonate's microbiome lacking maternal commensals [50]. After birth, either by vaginal delivery or $\mathrm{C}$-section, breast feeding provides the infant with Human Milk Oligosaccharides which are much more than just food for bacteria as originally proposed for the child [51]. The HMOs also are antiadhesive antimicrobials that serve as soluble decoy receptors, preventing pathogens attachment to the infant's mucosal surfaces and thereby lowering the risk for viral, bacterial and protozoan parasite infections [52,53].

HMO's also reportedly modulate epithelial and immune cell responses, reducing excessive mucosal leukocyte infiltration and activation, lowering the risk for necrotizing enterocolitis and providing the infant with sialic acid, a potentially essential nutrient for brain development and cognition [54,55]. Formula does not have the same protective properties that breastmilk does and sadly, many pediatric dentists criticize breast feeding as being cariogenic, even though published research links the associated dental caries to additional carbohydrate intake and night feeding [56,57]. The benefits of breast feeding have been well documented, and the need to adjust the preventive dentistry protocol to accommodate breast feeding should be evident [58]. Although the World Health Organization recommends two years, mothers probably should breast feed their infants for a least a year, the time interval reported to be the found in early hominins, Australopithecus africanus [59]. Another benefit from breast feeding, besides developing the microbiome and immune modulation, could be regulation of metals, especially zinc and copper, protecting the neurological development of the infant [60-62].

Streptococcus mutans has long been considered the key pathogen for the development of dental caries, the most prevalent chronic disease of humans [63-65]. Efforts to reduce the levels of Streptococcus mutans in infants and children with xylitol and preventing dental caries have been successful, raising the question as to why this is not standard dental practice. 66-67 However, other bacterial and fungal organisms have now been closely identified with the development of dental caries [68]. Scardovia wiggsiae is a Bacillus bacterium found extensively associated with SevereEarly Childhood Caries [69]. Scardovia wiggsiae and Slackia exigua have been reported to be involved in the early caries development [70]. Candida albicans, a fungal organism, helps with the biofilm production by increasing the extracellular polysaccharide matrix which protects Streptococcus mutans from anti-microbials and commensals such as Streptococcus oralis [71]. Lactobacilli inhibit the colonization of Candida albicans, hence decreasing the polysaccharide matrix, exposing the Streptococcus mutans to the bactericins or hydrogen peroxide of its natural competitors, other Streptococcus species [72]. Streptococcus oralis produces hydrogen peroxide that inhibits the anaerobic Streptococcus mutans growth $[73,74]$. Indeed, Probiora probiotic, a commercially available probiotic product, contains Streptococcus oralis, uberis and rattus, and claims to inhibit several key dental pathogens [7577]. Probiotics have been reported to be an important adjunct in preventive dental care [78-80].

Erythritol and xylitol are polyols that have been extensively researched and demonstrated to have notable anti-cariogenic and anti-periodontal disease properties [81,82]. Polyols (particularly the non-hexitol alditols or sugar alcohols erythritol and xylitol) have been found effective in inhibiting the transition to and maturation of biofilms from planktonic cells [83]. Xylitol clearly inhibited the formation of mixed species biofilms, which included Porphyromonas gingivalis in vitro [84]. Erythritol suppressed the maturation of gingivitis biofilms and contributed to a healthier oral ecosystem [85]. Porphyromonas gingivalis takes advantage of early colonizers (Streptococci and Candida) to provide attachment and protection within the biofilm matrix. Polyols can reduce extracellular polysaccharide production and interfere with biofilm matrix elaboration, thereby reducing adherence and biofilm development [86-88]. Streptococci and Candida utilize common dietary sugars sucrose and D-glucose for preferred energy sources, as well as for polysaccharide production. Higher glucose concentrations stimulate Candida growth. Compared with common D-sugars, xylitol induced the lowest adhesion and biofilm formation on either Streptococcus mutans or Candida albicans [89]. In addition, xylitol has been demonstrated to decrease the levels of cariogenic bacteria while having little effect on beneficial bacteria [90]. The discovery of bacteriophages specific for certain strains of Streptococcus mutans also show great promise in the management of pediatric oral health [91]. With the costs of dental disease rapidly escalating, now (2010) estimated at 442 billion US 
dollars, all effective measures to prevent oral disease should be urgently started in the pediatric population [92].

The Airway evaluation of the infant/toddler is of paramount importance during the first Age One examination [31]. Airway issues in children have been linked to future obesity, diabetes and behavioral issues [94,95]. Mouth breathing increases the oral microbiome pathogenic potential, as the incoming air will reduce the protective nature of the saliva [96]. Studies have demonstrated the correlation between oral disease and airway pathology $[97,98]$ Sleep Disturbed Breathing in children has been extensively reviewed in the literature, describing an ever-increasing pathologic chain of events $[99,100]$. Amongst the deleterious effects of mouth breathing are lower and mid-facial adaptations, orthodontic malocclusions, potential speech issues, esthetic concerns, sleep disturbed bruxism, and future temporomandibular joint dysfunctions [101-104]. The key to the future health of children is effective preventive care. What becomes a serious morbidity in adulthood started in childhood. Now more than ever, pediatric health care providers need to emphasize the connection between the oral health of children and their systemic health, with all the future ramifications now clearly reported in the scientific literature. The importance of the oral microbiome, its role as a "gateway" microbiome, and the systemic connection need to be more fully explained to patients, parents and all health care professionals.

Interestingly, the oral health care of the child starts before birth, requiring the participation of all involved in pre-natal care. It is now obvious that what is most important may be the microbiome, and how it is affected by the environment, diet, sleep, exercise, antibiotics, polyols and probiotics. The microbiome then modulates the immune system, allergies, resistance to pathogens, autoimmune responses, and ultimately patient health and longevity. At last, there seems to be great interest in the importance of pediatric and general oral health due to the crisis that poor oral health is bringing upon us [105]. We should be concerned that research studies from several countries have all reported neurotoxicity effects from relatively low levels of fluoride in children [106111]. Our over reliance on fluoride to create fluorapatite to inhibit decay seems inadequate at best. Perhaps this means that the time has come to treat a bacterial disease, as a bacterial disease. After all, dental caries and periodontal disease, and to a great extent downstream comorbidity including atherosclerosis, diabetes, strokes, inflammatory Alzheimer's, diabetes, and many systemic illnesses, can be traced back to a "dysbiosis" started in infancy.

\section{References}

1. Lone Survivors (2012) How we came to be the only humans on earth Chris Stringer. Times Books. Henry Holt and Company.

2. Zilber Rosenberg I, Rosenberg E (2008) Role of microorganisms in the evolution of animals and plants: the hologenome theory of evolution. FEMS Microbiol Rev 32: 723-735.

3. Huitzil S, Sandoval Motta S, Frank A, Aldana M (2018) Modeling the Role of the Microbiome in Evolution. Frontiers in physiology 9: 1836.

4. Ley RE, Peterson DA, Gordon JI (2006) Ecological and evolutionary forces shaping microbial diversity in the human intestine. Cell 124(4):
837-848.

5. Blaser MJ, Falkow S (2009) What are the consequences of the disappearing human microbiota? Nat Rev Microbiol 7(12): 887-894.

6. Okada H, Kuhn C, Feillet H, Bach JF (2010) The 'hygiene hypothesis' for autoimmune and allergic diseases: an update. Clinical and experimental immunology 160(1): 1-9.

7. Abt MC, Artis D (2013) The dynamic influence of commensal bacteria on the immune response to pathogens. Current opinion in microbiology 16(1): 4-9.

8. Collado MC, Rautava S, Aakko J, Isolauri E, Salminen S (2016) Human gut colonisation may be initiated in utero by distinct microbial communities in the placenta and amniotic fluid. Sci Rep 6: 23129.

9. Jimenez E, Marin ML, Martin R, Odriozola JM, Olivares M, et al. (2008) Is meconium from healthy newborns actually sterile? Res Microbiol 159(3): 187-193.

10. Baldassarre ME, Palladino V, Amoruso A, Pindinelli S, Mastromarino P, et al. (2018) Rationale of Probiotic Supplementation during Pregnancy and Neonatal Period. Nutrients 10(11): 1693.

11. Luoto R, Laitinen K, Nermes M, Isolauri E (2010) Impact of maternal probiotic-supplemented dietary counselling on pregnancy outcome and prenatal and postnatal growth: a double-blind, placebo-controlled study. Br J Nutr 103(12): 1792-1799.

12. Söderling E, Isokangas P, Pienihäkkinen K, Tenovuo J, Alanen P (2001) Influence of maternal xylitol consumption on mother-child transmission of mutans streptococci: 6-year follow-up. Caries Res 35(3): 173-177.

13. Prince A L, Ma J, Kannan PS, Alvarez M, Gisslen T, et al. (2016) The placental membrane microbiome is altered among subjects with spontaneous preterm birth with and without chorioamnionitis. American journal of obstetrics and gynecology, 214(5): 627.e1-627.e16.

14. Aagaard K, Ma J, Antony KM, Ganu R, Petrosino J (2014) The placenta harbors a unique microbiome. Science translational medicine 6(237): 237-265.

15. Romano-Keeler J, Weitkamp JH (2015) Maternal influences on fetal microbial colonization and immune development. Pediatric research 77(1-2): 189-195.

16. Pablo F Perez, Joël Doré, Marion Leclerc, Florence Levenez, Jalil Benyacoub, et al. (2007) Bacterial Imprinting of the Neonatal Immune System: Lessons from Maternal Cells? Pediatrics 119(3): 724-732.

17. Yajima M, Nakayama M, Hatano S, Yamazaki K, Aoyama Y, et al. (2001) Bacterial translocation in neonatal rats: the relation between intestinal flora, translocated bacteria, and influence of milk. J Pediatr Gastroenterol Nutr 33(5): 592-601.

18. Nyangahu DD, Lennard KS, Brown BP, Darby MG, Wendoh JM, et al. (2018). Disruption of maternal gut microbiota during gestation alters offspring microbiota and immunity. Microbiome 6(1): 124.

19. Nørrisgaard PE, Haubek D, Kühnisch J, Chawes BL, Stokholm J, et al. (2019) Association of High-Dose Vitamin D Supplementation During Pregnancy with the Risk of Enamel Defects in Offspring: A 6-Year Followup of a Randomized Clinical Trial. JAMA Pediatr.

20. Ley RE, Turnbaugh PJ, Klein S, Gordon JI (2006) Microbial ecology: human gut microbes associated with obesity. Nature 444: 1022-1023.

21. Brown K, DeCoffe D, Molcan E, Gibson DL (2012) Diet-induced dysbiosis of the intestinal microbiota and the effects on immunity and disease. Nutrients 4: 1095-1119.

22. Clarke SF, Murphy EF, O’Sullivan O, Lucey AJ, Humphreys M, et al. (2014) Exercise and associated dietary extremes impact on gut microbial diversity. Gut 63: 1913-1920.

23. Caufield PW, Cutter GR, Dasanayake AP (1993) Initial acquisition of mutans streptococci by infants: Evidence for a discrete window of 
infectivity. J Dent Res 72: 37-45.

24. Isokangas $P$, Söderling E, Pienihäkkinen K, Alanen P (2000) Occurrence of dental decay after maternal consumption of xylitol chewing gum, a follow-up from 0 to 5 years of age. J Dent Res 79: 1885-1889.

25. Loesche WJ, Grossman NS, Earnest R, Corpron R (1984) The effect of chewing xylitol gum on the plaque and saliva levels of Streptococcus mutans. J Am Dent Assoc 108: 587-592.

26. Falsetta ML, Klein MI, Colonne PM, et al. (2014) Symbiotic relationship between Streptococcus mutans and Candida albicans synergizes virulence of plaque biofilms in vivo. Infect Immun 82(5): 1968-1981.

27. Koo H, Bowen WH (2014) Candida albicans and Streptococcus mutans: a potential synergistic alliance to cause virulent tooth decay in children. Future Microbiol 9(12): 1295-1297.

28. Hatakka K, Ahola AJ, Yli-Knuuttila H, Richardson M, Poussa T, et al. (2007) Probiotics reduce the prevalence of oral Candida in the elderly-a randomized controlled trial. J Dent Res 86(2): 125-130.

29. Hasslof P, Hedberg M, Twetman S, Stecksen-Blicks C (2010) Growth inhibition of oral mutans streptococci and Candida by commercial probiotic lactobacilli-an in vitro study. BMC Oral Health 10: 18.

30. Kohler GA, Assefa S, Reid G (2012) Probiotic interference of Lactobacillus rhamnosus GR-1 and Lactobacillus reuteri RC-14 with the opportunistic fungal pathogen Candida albicans. Infect Dis Obstet Gynecol, pp. 636474.

31. Suhyun K, Dong GL (2019) Role of calcium in reactive oxygen speciesinduced apoptosis in Candida albicans: an antifungal mechanism of antimicrobial peptide, PMAP-23, Free Radical Research 53(1): 8-17.

32. Du H, Guan G, Li X, Gulati M, Tao L, et al. (2015) N-AcetylglucosamineInduced Cell Death in Candida albicans and Its Implications for Adaptive Mechanisms of Nutrient Sensing in Yeasts. mBio 6(5): e01376-15.

33. Peedikayil FC, Remy V, John S, Chandru TP, Sreenivasan P, et al. (2016) Comparison of antibacterial efficacy of coconut oil and chlorhexidine on Streptococcus mutans: An in vivo study. Journal of International Society of Preventive \& Community Dentistry 6(5): 447-452.

34. Ogbolu DO, Oni AA, Daini OA, Oloko AP (2007) In vitro antimicrobial properties of coconut oil on Candida species in Ibadan, Nigeria. J Med Food 10(2): 384-387.

35. Shino B, Peedikayil FC, Jaiprakash SR, Ahmed Bijapur G, Kottayi, et al. (2016) Comparison of Antimicrobial Activity of Chlorhexidine, Coconut Oil, Probiotics, and Ketoconazole on Candida albicans Isolated in Children with Early Childhood Caries: An In Vitro Study. Scientifica : 7061587.

36. Gunsalus KT, Tornberg Belanger SN, Matthan NR, Lichtenstein AH, Kumamoto, et al. (2015) Manipulation of Host Diet to Reduce Gastrointestinal Colonization by the Opportunistic Pathogen Candida albicans. mSphere 1(1): e00020-15.

37. Wang Y, Liu Z, Han Y, Xu J, Huang W, et al. (2018) Medium Chain Triglycerides enhances exercise endurance through the increased mitochondrial biogenesis and metabolism. PloS one 13(2): e0191182.

38. Akca, AE, Akca G, Topçu FT, Macit E, Pikdöken L, et al. (2016) The Comparative Evaluation of the Antimicrobial Effect of Propolis with Chlorhexidine against Oral Pathogens: An In Vitro Study. BioMed research international 2016(1): 1-8.

39. Morawiec T, Mertas A, Wojtyczka RD, Niedzielska, I, Dziedzic A, et al (2015) The Assessment of Oral Microflora Exposed to 3\% Ethanolic Extract of Brazilian Green Propolis Preparation Used for Hygiene Maintenance following Minor Oral Surgeries. BioMed research international, pp. 869575.

40. Niedzielska I, Puszczewicz Z, Mertas A, Niedzielski D, Różanowski B, et al. (2016) The Influence of Ethanolic Extract of Brazilian Green Propolis Gel on Hygiene and Oral Microbiota in Patients after Mandible Fractures.
BioMed research international 12: 1-11.

41. Xiao J, Moon Y, Li L, Rustchenko E, Wakabayashi H, et al. (2016) Candida albicans Carriage in Children with Severe Early Childhood Caries (S-ECC) and Maternal Relatedness. PloS one 11(10): pp. 164242.

42. Southward K (2015) A hypothetical role for vitamin K2 in the endocrine and exocrine aspects of dental caries. Med Hypotheses 84(3): 276-280.

43. Granados H, Glavind J, Dam H (1949) Observations on experimental dental caries; the effect of certain quinones with, and without vitamin $\mathrm{K}$ activity. Acta Pathol Microbiol Scand 26(4): 597-602.

44. Schroth RJ, Levi JA, Sellers EA, Friel J, Kliewer E (2013) Vitamin D status of children with severe early childhood caries: a case-control study. BMC Pediatr 13(174): 1-810.

45. Hujoel PP (2013) Vitamin D and dental caries in controlled clinical trials: systematic review and meta-analysis. Nutr Rev 71(2): 9688-9711.

46. Schroth RJ, Jeal NS, Kliewer E, Sellers EA (2012) The relationship between vitamin $\mathrm{D}$ and severe early childhood caries: a pilot study. Int J Vitam Nutr Res 82(1): 53-62.

47. Brown T, Creed S, Alexander S, Barnard K, Bridges N, et al. (2012) Vitamin D deficiency in children with dental caries -a prevalence study. Arch Dis Child 97(1): 1-186.

48. Elde SJ, Haytowitz DB, Howe J, Peterson JW, Booth, SL (2006) Vitamin $\mathrm{k}$ contents of meat, dairy, and fast food in the US Diet. Journal of agricultural and food chemistry 54(2): 463-467

49. Montoya Williams D, Lemas DJ, Spiryda L, Patel K, et al. (2018) The Neonatal Microbiome and Its Partial Role in Mediating the Association between Birth by Cesarean Section and Adverse Pediatric Outcomes. Neonatology 114(2): 103-111.

50. Neu J, Rushing J (2011) Cesarean versus vaginal delivery: long-term infant outcomes and the hygiene hypothesis. Clinics in perinatology 38(2): 321-331.

51. Marcobal, A, Sonnenburg JL (2012) Human milk oligosaccharide consumption by intestinal microbiota. Clinical microbiology and infection: the official publication of the European Society of Clinical Microbiology and Infectious Diseases 4(4): 12-15.

52. Yu Y, Lasanajak Y, Song X, Hu L, Ramani S, et al. (2014). Human milk contains novel glycans that are potential decoy receptors for neonatal rotaviruses. Molecular \& cellular proteomics: MCP 13(11): 2944-2960.

53. Triantis V, Bode, L, van Neerven R (2018) Immunological Effects of Human Milk Oligosaccharides. Frontiers in pediatrics 6:190.

54. Plaza Díaz J Fontana L, Gil, A (2018) Human Milk Oligosaccharides and Immune System Development. Nutrients 10(8): 1038.

55. Bode L (2012) Human milk oligosaccharides: every baby needs a sugar mama. Glycobiology 22(9): 1147-1162.

56. Hong L, Levy SM, Warren JJ, Broffitt, B (2014) Infant breast-feeding and childhood caries: a nine-year study. Pediatric dentistry 36(4): 342-347.

57. Avila WM, Pordeus IA, Paiva SM, Martins CC (2015) Breast and Bottle Feeding as Risk Factors for Dental Caries: A Systematic Review and Meta-Analysis. PloS one 10(11): e0142922.

58. Joannes Boyau R (2018) Elemental signatures of Australopithecus africanus teeth reveal seasonal dietary stress. Nature. 572(7767): 112115.

59. Curtin P, Austin C, Curtin A, Gennings C, Arora M (2018) Dynamical features in fetal and postnatal zinc-copper metabolic cycles predict the emergence of autism spectrum disorder. Science advances 4(5): 1293.

60. Crane JK, Broome JE, Reddinger RM, Werth BB (2014) Zinc protects against Shiga-toxigenic Escherichia coli by acting on host tissues as well as on bacteria. BMC microbiology 14: 145. 
61. Hampel D, Dror DK, Allen LH (2018) Micronutrients in Human Milk: Analytical Methods. Adv Nutr 9(suppl_1): 313-331.

62. Munblit D, Peroni DG, Boix Amoros A, Hsu PS, Van't Land B et al. (2017) Human Milk and Allergic Diseases: An Unsolved Puzzle. Nutrients 9(8): 894.

63. Clarke JK (1924) On the bacterial factor in the etiology of dental caries. Brit J Exp Pathol 5: 141-147.

64. Loesche WJ (1986) Role of Streptococcus mutans in human dental decay. Microbiol Rev 50(4): 353-380.

65. Lemos JA, Palmer SR, Zeng L, Wen ZT, Kajfasz JK et al. (2019) The Biology of Streptococcus mutans. Microbiol Spectr 7(1).

66. Mäkinen, KK, Järvinen KL, Anttila CH, Luntamo LM, Vahlberg T (2013) Topical xylitol administration by parents for the promotion of oral health in infants: a caries prevention experiment at a Finnish Public Health Centre. Int Dent J 63(4): 210-224.

67. Milgrom P, Ly KA, Tut OK, Mancl L, Roberts MC, et al. (2009) Xylitol pediatric topical oral syrup to prevent dental caries: a double-blind randomized clinical trial of efficacy. Arch Pediatr Adolesc Med 163(7): 601-607.

68. Kuramitsu HK, Wang BY (2011) The whole is greater than the sum of its parts: dental plaque bacterial interactions can affect the virulence properties of cariogenic Streptococcus mutans. Am J Dent 24(3): 153154.

69. Kressirer CA, Smith DJ, King WF, Dobeck JM, Starr JR, et al. (2017) Scardovia wiggsiae and its potential role as a caries pathogen. Journal of oral biosciences 59(3): 135-141.

70. Tanner AC, Kent RL Jr, Holgerson PL, Hughes CV, Loo CY, et al. (2011) Microbiota of severe early childhood caries before and after therapy. J Dent Res 90(11): 1298-1305.

71. Xiao J, Huang X, Alkhers N, Alzamil H, Alzoubi S, et al. (2018) Candida albicans and Early Childhood Caries: A Systematic Review and MetaAnalysis. Caries res 52(1-2): 102-112.

72. Matsubara VH, Wang Y, Bandara HMHN, et al. (2016) Appl Microbiol Biotechnol 100: 6415 .

73. Bidossi A, De Grandi R, Toscano M, Bottagisio M, De Vecchi E, et al. (2018) Probiotics Streptococcus salivarius 24SMB and Streptococcus oralis 89a interfere with biofilm formation of pathogens of the upper respiratory tract. BMC infect dis 18(1): 653.

74. Hillman JD, Socransky SS, Shivers M (1985) The relationships between streptococcal species and periodontopathic bacteria in human dental plaque. Arch Oral Biol 30(11-12): 791-795.

75. Hedayati Hajikand T, Lundberg U, Eldh C, Twetman S (2015) Effect of probiotic chewing tablets on early childhood caries--a randomized controlled trial. BMC oral health 15(1): 112.

76. Hillman JD, Socransky SS (1989) The theory and application of bacterial interference to oral diseases. In New Biotechnology in Oral Research. ed. Myers HM (Basel: S Karger) 1-17.

77. Zahradnik RT, Magnusson I, Walker C, McDonell E, Hillman CH (2009) Preliminary assessment of safety and effectiveness in humans of ProBiora3, a probiotic mouthwash. J Applied Micro 107(2): 682-690.

78. Hillman JD, McDonell E, Hillman CH, Zahradnik RT, Soni MG (2009) Safety assessment of ProBiora3, a probiotic mouthwash; subchronic toxicity study in rats. Int J Toxicol 28(5): 357-367.

79. Cannon M (2011) A Review of Probiotic Therapy in Preventive Dental Practice. Probiotics Antimicrob Proteins 3(2): 63-67.

80. Cannon M, Trent B, Vorachek A, Kramer S, Esterly R (2013) Effectiveness of CRT at measuring the salivary level of bacteria in caries prone children with probiotic therapy. J Clin Pediatr Dent 38(1): 55-60.
81. Cannon M (2011) Clinical Application of Probiotic Therapy. Inside Dentistry 7(6): 112-113.

82. Janakiram C, Deepan Kumar CV, Joseph J (2017) Xylitol in preventing dental caries: A systematic review and meta-analyses. J Nat Sci Biol Med 8(1): 16-21.

83. Sánchez MC, Romero Lastra P, Ribeiro Vidal H, Llama Palacios A, Figuero E et al. (2019) Comparative gene expression analysis of planktonic Porphyromonas gingivalis ATCC 33277 in the presence of a growing biofilm versus planktonic cells. BMC Microbiol 19(1):58.

84. Badet C, Furiga A, Thébaud N (2008) Effect of xylitol on an in vitro model of oral biofilm. Oral Health Prev Dent 6(4): 337-341.

85. Marleen Marga Janus, Catherine Minke Charlotte Volgenant, Bernd Willem Brandt, Mark Johannes Buijs, Bart Jan Frederik Keijser, Wim Crielaard, Egija Zaura, et al. (2017) Effect of erythritol on microbial ecology of in vitro gingivitis biofilms. Journal of Oral Microbiology 9(1): 1337477.

86. Söderling E, Hietala Lenkkeri AM (2010) Xylitol and erythritol decrease adherence of polysaccharide-producing oral streptococci. Curr Microbiol 60(1): 22-29.

87. Ferreira AS, Silva Paes Leme AF, Raposo NR, da Silva SS (2015) By Passing Microbial Resistance: Xylitol Controls Microorganisms Growth by Means of Its Anti-Adherence Property. Curr Pharm Biotechnol 16(1): 35-42.

88. Ghezelbash, G.R., Nahvi I., Rabbani M (2012) Comparative inhibitory effect of xylitol and erythritol on the growth and biofilm formation of oral Streptococci. African Journal of Microbiology Research 6(20): 44044408.

89. Brambilla E, Ionescu AC, Cazzaniga G, Ottobelli M, Samaranayake LP (2015) Levorotatory carbohydrates and xylitol subdue Streptococcus mutans and Candida albicans adhesion and biofilm formation. J Basic Microbiol 56(5): 480-492.

90. Bahador A, Lesan S, Kashi N (2012) Effect of xylitol on cariogenic and beneficial oral streptococci: a randomized, double-blind crossover trial. Iranian journal of microbiology 4(2): 75-81.

91. Dalmasso M, de Haas E, Neve H, Strain R, Cousin FJ, Stockdale SR, Hill C (2015) Isolation of a Novel Phage with Activity against Streptococcus mutans Biofilms. PloS one 10(9): 138651.

92. Listl S, Galloway J, Mossey PA, Marcenes W (2015) Global Economic Impact of Dental Diseases. J Dent Res 94(10): 1355-1361.

93. Katz ES, Mitchell RB, DAmbrosio CM (2012) Obstructive sleep apnea in infants. American journal of respiratory and critical care medicine 185(8): 805-816.

94. Surani SR (2014) Diabetes, sleep apnea, obesity and cardiovascular disease: Why not address them together? World Journal of Diabetes 5(3): 381-384.

95. Biggs SN, Vlahandonis A, Anderson V, Bourke R, Nixon GM, et al. (2014) Long-term changes in neurocognition and behavior following treatment of sleep disordered breathing in school-aged children. Sleep 37(1): 7784.

96. Mummolo S, Nota A, Caruso S, Quinzi V, Marchetti E, et al. (2018) Salivary Markers and Microbial Flora in Mouth Breathing Late Adolescents. BioMed research international, pp. 8687608.

97. Sanders AE, Essick GK, Beck JD, Cai J, Beaver S, et al. (2015) Periodontitis and Sleep Disordered Breathing in the Hispanic Community Health Study/Study of Latinos. Sleep 38(8): 1195-1203.

98. Xu H, Li X, Zheng X, Xia Y, Fu Y, et al. (2018) Pediatric Obstructive Sleep Apnea is Associated with Changes in the Oral Microbiome and Urinary Metabolomics Profile: A Pilot Study. Journal of clinical sleep medicine : JCSM : official publication of the American Academy of Sleep Medicine 14(9): 1559-1567. 
99. Bonuck K, Freeman K, Chervin RD, Xu L (2012) Sleep-disordered breathing in a population-based cohort: behavioral outcomes at 4 and 7 years. Pediatrics 129(4): 857-865.

100. Bonuck K, Rao T, Xu L (2012) Pediatric sleep disorders and special educational need at 8 years: a population-based cohort study. Pediatrics 130(4): 634-642.

101. Bonuck K, Chervin RD, Howe LD (2015) Sleep-disordered breathing, sleep duration, and childhood overweight: a longitudinal cohort study. The Journal of pediatrics 166(3): 632-639.

102. Muzumdar H, Arens R (2013) Physiological effects of obstructive sleep apnea syndrome in childhood. Respiratory physiology \& neurobiology 188(3): 370-382.

103. Arali V, Namineni S, Sampath CH (2012) Pediatric obstructive sleep apnea syndrome: time to wake up. International journal of clinical pediatric dentistry 5(1): 54-60.

104. Sanders AE, Essick GK, Fillingim R, Knott C, Ohrbach R, et al. (2013) Sleep apnea symptoms and risk of temporomandibular disorder: OPPERA cohort. Journal of Dental Research 92(7 Suppl): 70-77.
105. Watt RG, Daly B, Allison P, Macpherson LMD, Venturelli R, et al. (2019) Ending the neglect of global oral health: time for radical action. Lancet 394(10194): 261-272.

106. Green R (2019) Association between maternal fluoride exposure during pregnancy and IQ scores in offspring in Canada. JAMA Pediatrics.

107. Bellinger DC (2019) Is fluoride potentially neurotoxic? JAMA Pediatrics.

108. Christakis D (2019) Decision to publish study on maternal fluoride exposure during pregnancy. JAMA Pediatrics.

109. Pereira M, Dombrowski PA, Losso EM, Chioca LR, Da Cunha C, et al. (2011) Memory impairment induced by sodium fluoride is associated with changes in brain monoamine levels. Neurotox Res 19(1): 55-62.

110. Jiang C, Zhang S, Liu H (2014) Low glucose utilization and neurodegenerative changes caused by sodium fluoride exposure in rat's developmental brain. Neuromolecular Med 16(1): 94-105.

111. Choi AL, Sun G, Zhang Y, Grandjean P (2012) Developmental fluoride neurotoxicity: a systematic review and meta-analysis. Environ Health Perspect 120(10): 1362-1368.

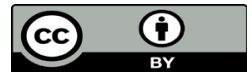

This work is licensed under Creative Commons Attribution 4.0 License

To Submit Your Article Click Here:

Submit Article

DOI: $10.32474 /$ IPDOAJ.2019.03.000158

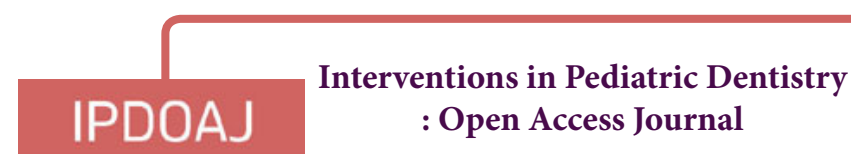

Assets of Publishing with us

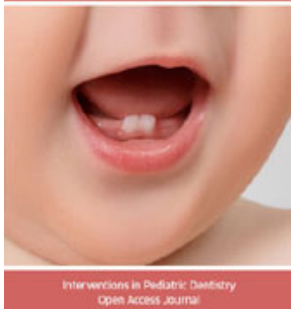

- Global archiving of articles

- Immediate, unrestricted online access

- Rigorous Peer Review Process

- Authors Retain Copyrights

- Unique DOI for all articles 